УдК $\quad 316.662-053.9(497.11) " 20 "$

305-055.2:791.4"20"

DOI https://doi.org/10.31212/tokovi.2019.3.gud.171-189

Оригинални научни рад

Примљен: 27. 7.2019.

Прихваћен: 3. 9.2019.

Vera GUDAC DODIĆ

Institute for Recent History of Serbia, Belgrade

luvenido@ptt.rs

\title{
Aging in Serbia in the Twentieth Century: A Gender Perspective ${ }^{*}$
}

\begin{abstract}
The text sheds light on some research questions regarding the gender aspects of the past. It gives basic notes on accelerated demographic aging, as well as a historical review of the processes of aging in Serbia and gender inequality among the older generations, i.e. the feminization of the past. This work also includes presentations and perceptions of old age, thus older women, as well as how they are presented in domestic films.
\end{abstract}

Key words: Demographic Aging, Feminization of the Past, Women of the Third Age, Presenting Old Age

In Serbia, the population's aging process is being increasingly emphasized and is a significant characteristic of the country's demographic picture. Serbia ranks at the very top of Europe in terms of population exceeding 65 years of age; it is one of the countries with the oldest population. The average age of the inhabitants of the Republic of Serbia in 2017 was 43 years old, ${ }^{1}$ and the percentage of people aged over 65 in comparison to the entire population is $19.6 \% .^{2}$ As early as the following year, in 2018 , the average age grew to 43.2 years old ( 41.7 for men and 44.5 for

\footnotetext{
* The article is a result of work on the project Tradition and Transformation - Historical Heritage and National Identities in Serbia in the Twentieth Century (No 47019), funded by the Ministry of Education, Science and Technological Development.

1 In 2017, the average age within the male population was 41.6, and 44.4 years old within the female. Статистички годишњак Републике Србије 2018, (Републички завод за статистику, Република Србија), 37.

2 Статистички годишњак Републике Србије 2018, 25.
} 
women). ${ }^{3}$ This state in which almost a fifth of the population is over 65 years old affects Serbia's entire social development, significantly determines it, and has strong economic and social implications. ${ }^{4}$

In that context, researching old age from different perspectives, the consequences and outcomes of aging, is of great importance. The theme of the gender aspects of aging is especially important. Demographic research - which treats the effect of gender differences on particular phenomena and analyzes the links between those differences and their appropriate behavior, thus contributing to a better understanding of demographic processes and social development - are more and more common in the world. ${ }^{5}$ Numerous aspects of female aging encompass a number of different questions. ${ }^{6}$ Research questions related to the gender dimensions of old age involve an analysis of different segments, such as ethical aspects, conditions in which older women live, financial opportunities and the economic position of women in old age, family relations as well as relationships they build with other people, questions related to health aspects, corporeality, spirituality, care, the presentation of old age in the media, elements of "agism-sexism in language, literature, and art"...

The question of women aging, numerous problems that it opens and the consequences of aging in different spheres, describes all of society, points to its domains in economic and social development, the accepted values. The relationship with the elderly portrays a society more than a number of other indicators of the social and cultural level of its devel-

3 http://data.stat.gov.rs/Home/Result/180708?languageCode=sr-Latn, Република Србија, Републички завод за статистику, Просечна старост, по полу.

4 Aside from others, it strongly reflects on the pension system, increasingly burdening the workforce of residents.

5 The relationship between working women and the average number of children, gender differences and economic activity, behavior in marriage, the stability of marriage, as well as cohabitation, the relationship between the differences in mortality and social standing of the genders, etc. was analyzed. Ankica, Šobot, "Rodna neravnopravnost - izazov savremene demografije”, Sociologija, Vol. LII, N 1, 2010, 46; Ankica Šobot, Rodna neravnopravnost u Srbiji: Demografsko gledište, (Beograd: Institut društvenih nauka, 2014); Ankica Šobot, "Tri demografske posledice rodno specifičnih modela ponašanja na primeru Srbije", Stanovništvo 2, 2012, 85-109.

6 Among the few research projects in Serbia which problematise and analyse old age from the gender perspective is the research by Ankica Šobot, "Demografski okvir rodne neravnopravnosti i kvalitet života u starosti", Geronotlogija, br. 1, 2011, 29-48.

7 Those are some of the problems and segments of the analysis which are covered by feminist and gerontological research of the ageing of women. Marija Geiger Zeman, "'Kažu da prije stare žene nego muški' - starost i starenje kao relevantna feministička pitanja", Treća, vol. XVI, br. 1-2: Starosrt i starenje: dvostruka mjerila i tabui, 2014, 8-9. 
opment. The gender perspective on aging, the aspects in which old age in women is manifested and reflected, its consequences and repercussions, are questions open for future research in this region.

\section{The Aging of Women, a Historical Perspective}

The historical development of society and its developmental processes, political circumstances, economic and healthcare conditions in the twentieth century, are what has influenced the courses in demographic trends in Serbia, conditioned the changes in the population's age and gender structure. Wars, the different reality they created, the victims and the suffering of people, contagious disease epidemics at the start of the century, as well as migrations of the population as seen in the second part of the century, especially at the end of the twentieth and beginning of the twenty-first century, are the frame to understanding the demographic trends and following the processes of the aging of the population, as well as changes in the balance of the gender structure.

At the very beginning of the twentieth century, Serbia had a distinctly young population. According to the 1900 census, the male population was more numerous. The wars at the beginning of the twentieth century decreased the entire population and contributed to the gender disbalance because many more men died and therefore brought about changes in the age structure. ${ }^{8}$

Other research shows that women lived shorter lives than men at the beginning of the twentieth century in Serbia. ${ }^{9}$ Thus in 1903, women in cities had an average lifespan of 40.66 years, and men 50.93 years. In rural areas, the average lifespan for women was 41.74 years and 49.69 years for men. ${ }^{10}$ At the time, unlike in many European countries, there were fewer women in Serbia than men. In early childhood, male children died more than female, but the number of women who died increased sig-

$8 \quad$ That was especially prominent in parts where most people died during the First World War. Momčilo Isić, "Starosna struktura stanovništva u Srbiji početkom 20. veka - posledice ratnih stradanja", Gerontologija, časopis gerontološkog društva Srbije, 2009, 99, 102.

9 Dubravka Stojanović, „,U senci velikog narativa': Stanje zdravlja žena i dece u Srbiji početkom XX veka", Žene i deca, Srbija u modernizacijskim procesima XIX i XX veka, 4, (Beograd, 2006), 160-175.

10 The data refers to the married, because the average age of those that died was significantly lower due to the high mortality rate of infants and children. Compare: Статистички годишњак Краљевине Србије 1903, (Београд, 1906), Table: Просечна година старости умрлих, 176; http://www.stat.gov.rs/sr-latn/publikacije/ 
nificantly after puberty. The sudden rise in female mortality was characteristic of the period of female sexual maturity. Women often died during childbirth due to poor and unhygienic conditions, and thus childbirth was one of the main causes of a shorter lifespan. ${ }^{11}$

Numerous factors affected the further demographic development in Serbia, above all the increased lifespan of the population. Extended old age in women was a result of changed circumstances, such as improvements in healthcare, delivery conditions in childbirth, the reduction of childbirth and abortion mortality, better quality of life and basic living conditions, nutrition, etc. General hygiene and healthcare conditions were still very poor immediately after the World War II, sometimes even horrible, especially in rural, underdeveloped areas, and in the more remote provinces of Serbia. ${ }^{12}$ Even basic conditions were often lacking, as well as an awareness of the need to maintain basic and personal hygiene. In the context of socialist development, the state made a number of attempts to implement different measures and actions ${ }^{13}$ with the goal of improving health culture and creating a change in habits, primarily among women in the countryside. In the first post-war years, women still often fell ill due to unhealthy conditions, as well as lacking hygiene during pregnancy and childbirth, and the mortality rate of infants was still very high. Such a sit-

11 Stojanović „U senci velikog narativa“, 162-163.

12 Much like in the first half of the century, women often gave birth to children while working, in the field, in the hay over which dirty and torn sacks were thrown. Arhiv Srbije (Archives of Serbia - AS), CK SKS Fund, Commission for National Authority, K234, Health and National Authority Report; Вера Гудац Додић, Жена у социјализму, (Београд, 2006), 136-137. There was a belief in the surroundings of Vranje that women had to give birth on their own and take shelter somewhere secluded in doing so. In Kosovo, women gave birth on the ground, in barns, and in the filthiest of places, because it was thought that pregnant women were unclean and that they couldn't give birth in bed. Newborns would hit their heads on the floor at birth. Ivana Dobrivojević, Selo i grad, Transformacija agrarnog društva Srbije 1945-1955, (Beograd: ISI, 2013), 254. Horrible conditions in which women gave birth to children weren't only characteristic of the deep provinces of Serbia, but those births sometimes happened near the capital, too. "Even today it happens that women in the villages in Srem give birth on the floor and on straw, despite the white bed; poppy is cooked for the crying child so it can go to sleep. Those cases exist on the reach of Belgrade itself." Istorijski arhiv Beograda (Historical Archive of Belgrade - IAB), Conference for the Social Activity of Women, k. 3 , Shorthand Notes from the Annual Assembly of the Union of Women's Societies of Belgrade, June 1, 1956; Гудац Додић, Жена у социјализму, 137.

13 Healthcare and hygiene courses, mobile groups that went around villages, but also other mass actions, numerous multi-month courses, lectures, articles published in the press etc., were some of the many state activities through which the state attempted to educated, elevate the level of health culture and basic knowledge of the women in villages. 
uation changed with time; conditions in which women gave birth became better, and the majority of women gave birth in hospitals, with expert help. The legalization of planned termination of pregnancy slowly eradicated illegal abortions that tended to endanger the health and life of women because of the primitive and foul ways in which they were performed. ${ }^{14}$ The second part of the twentieth century saw the establishment of numerous institutions for the protection of women's, mothers', and children's health. ${ }^{15}$

In 1950, only a fifth of the women, mostly in urban areas, gave birth in hospitals. At the beginning of the 1960s, only just over half of expectant mothers $(52.5 \%)$ gave birth with the assistance of a midwife or doctor. Other women did not have expert help during childbirth, and these were mostly women living in rural areas. ${ }^{16}$ The high mortality rate in newborns and babies up to one year old is one of the emphasized problems which the socialist government faced. Almost a fourth of the rural women still gave birth in their homes in the 1980s, healthcare was insufficient, and the mortality of infants was greater than in towns and cities. ${ }^{17}$ Many villages lacked healthcare institutions and medical staff.

In the mid-twentieth century (1948), the population of Serbia - with $5.6 \%$ of people older than 65 years, the average age being 29.1 years, and the aging index 0.19 - was still among the youngest in Europe. The situation has changed significantly since the census of $2011,{ }^{18}$ because the portion of the older population had gone up to $17.4 \%$, the average age of the population to 42.4 years, and the aging index to 1.22 . The population's demographic aging process was a continuous trend in the second part of the century but had the highest intensity in the last decade. Very adverse political conditions and economic circumstances triggered the mass emigration of primarily young people, and thus a fall in fertility. This led to a state in

14 See more about the ways in which illegal abortions were carried out: Vera Gudac Dodić, Life in Serbia, Through the Eyes of Women, (Belgrade, 2014), 77-79. In Serbia, there was infanticide, not only in the first half of the twentieth century, but also in the post-war era, mostly in villages. In the Women's Antifascist Front of Yugoslavia documentation from 1949, in the state of children protection report, it is written that infanticide "exists in great measure". IAB, Konferencija za društvenu aktoivnost žena, Stanje dečije zaštite u Beogradu, 1949.

15 Vera Gudac Dodić, "Starenje ženskog stanovništva u Srbiji u drugoj polovini 20. veka", Gerontologija, časopis Gerantološkog društva Srbije, (Beograd), 2009, 144-146.

16 Tetanus was widely spread among newborn babies, in Serbia more "than in all other republics put together". AS, đ-75, f 92, Neki aktuelni problemi u vezi sa društvenim položajem žena na selu.

17 Arhiv Jugoslavije (Archives of Yugoslavia - AJ), 142, 468, Zadružni savez Jugoslavije, Beograd, 3. 4. 1980.

18 The data refers to the population which lived on the territory of Kosovo and Metohija. 
which the average age of the population increased from 37.2 to 40.2 in only three years during the time between 1991 and 2002. In two decades, from 1991 to 2011, the percentage of the old population grew by 6\%, an increase equal to that achieved in the previous fifty years. ${ }^{19}$ The unfavorable trends have continued, as shown in the data presented at the beginning of this text.

\section{The Feminization of Old Age}

Unlike at the beginning of the twentieth century, ${ }^{20}$ at its end, but also at the turn of the century, over half of the population, more than $51 \%$, was made up of women. ${ }^{21}$

After World War II, women were more dominant in numbers, followed by the processes of "balancing out the gender structure of the entire population," ${ }^{22}$ in other words, the domination of the female population in comparison to the total population had declined. From the 1980s, however, there has been an evident decline in the percentage of the male population. That trend was even more emphasized during the 1990s. The different contributing factors were the decline in fertility, a longer life expectancy in women, and, among other things, the "migrant selectivity in age and gender."23

Such a trend has continued, because there was $51.3 \%$ of women in comparison to the total population according to the 2011 census. On average, they live longer than men in Serbia. ${ }^{24}$ In 2011, the average age of women in Serbia was 43.5 years (41.5 in 2002), and the average age of men was 40.8 (39.3 in 2002). In comparison to the first decades of the previous century, in 1921, the average age of women had increased by 15

19 Mirjana Devedžić, Jelena Stojilković Gnjatović, Popis stanovništva, domaćinstava i stanova u 2011. Demografski profil stanovništva Srbije, (Beograd: Republički zavod za statistku, 2015), 21-22.

20 According to data from 1910, among the total population of Serbia, the number of men was greater (1.503.511) than the number of women (1.408.190). Table: Nastanjeno i prisutno stanovništvo po okruzima, Prethodni rezultati popisa stanovništva i domaće stoke u Kraljevini Srbiji 31. decembra 1910, knjiga peta, (Beograd: Izdanje uprave državne statistike, 1911), 4.

21 In 1991, there were 104 women per 100 men in Serbia and 106 women per 100 men in 2002. Жене и мушкарци у Србији, (Београд: Републички завод за статистику, 2005), 10, 11.

22 Горан Пенев, „Структура становништва према полу и старости“, у: Попис становништва, домаћинстава и станова 2011. у Републици Србији, Популација Србије почетком 21. века, (Београд: Републички завод за статистику, 2015), 131.

23 Ibid., 133.

24 The average life expectancy in 2011 in the Republic of Serbia was 76.82 years old for women and 71.63 years old for men. 
years, and the average age of men by 13 . The proportion of women in the population's age groups increases as the age increases. According to statistics, there are more women among middle-aged and older citizens, and more men among the younger population. ${ }^{25}$

The latest population estimates for 2017 have shown that the average age of women in Serbia is 44.4 years and 41.6 years for men, while life expectancy for male children is 73 years, and 77.9 years for female children. $^{26}$

According to data from the most recent census (2011), there were more men than women in all age groups up to 40 years old, ${ }^{27}$ a ratio that would change with the increase in age in favor of the female population. Thus, among the older population, from 65 to 69 , there were 184.669 women (154.775 men), from the ages of 70 to 74200.295 women (153.847 men), between the ages of 75 and 79175.648 women (122.964 men), from 80 to 84 years old 108.754 women (67.814 men), and in the oldest age group of the population from 85 and up, in Serbia there was almost twice as many women (53.883) as there were men $(27.667) .{ }^{28}$ The gender imbalance, i.e. the difference in the numbers in the female and male population, is especially evident among the oldest. Some of the reasons

25 Жене и мушкарци у Републици Србији, (Београд: Републички завод за статистику, 2017), 10.

26 Статистички годишњак Републике Србије 2018, (Београд, 2018), 37.

27 In Serbia, more boys than girls are born. 105 boys are born per every 100 newborn girls. Such a ratio between male and female children isn't only characteristic of Serbia, but is typical of other countries too. According to a report by the World Health Organization, such a proportion is natural and expected. Certain variables in the expected ratio at birth can move between 102 and 107 boys per 100 girls. However, at a global level, boys have a higher mortality rate than girls at the youngest age, slowly balancing out the ration between male and female children. Hannah Ritchie and Max Roser (2019) - "Gender Ratio". Published online at OurWorldInData.org. Retrieved from: 'https://ourworldindata.org/gender-ratio' [Online Resource] https:// ourworldindata.org/gender-ratio\#definitions, [Data Source: UN Population Division (2017 Revision); World Bank - World Development Indicators; Chao, F., Gerland, P., Cook, A. R., Alkema, L. (2019) Systematic assessment of the sex ratio at birth for all countries and estimation of national imbalances and regional reference levels. PNAS.] According to certain research, the birth of children in villages in Serbia was often dependent on the gender of the first child, the birth of a son was a priority. If the firstborn child is male, women often stopped having more children after its birth, whereas if the first child was a daughter, women would still keep giving birth until a male successor was born. Александра Павићевић, На удару идеологија. Брак, породица и полни морал у Србији у другој половини двадесетог века, (Београд: Етнографски институт САНУ, 2006), 260.

28 Статистички годишњак Републике Србије 2017, (Београд: Републички завод за статистику, 2017), 38. Data for Kosovo and Metohija are not shown. 
why women live longer than men may also be sought in the circumstances in which nearly twice as many men over women die between the ages of 30 and 59, primarily due to circulatory diseases and tumors. According to data from 2016, as many as four times more men die in car accidents. In that same year, three times more men than women committed suicide, and research for the previous year, 2015, shows that men smoked more than women... ${ }^{29}$ In addition to other factors, lifestyle has a significant influence on differences in the lifespan between men and women. The fact that women live longer than men and that they prevail among the oldest segments of the population points to the so-called feminization of old age.

Gender differences and the gender imbalance in Central Serbia are the most noticeable among the older population, especially in those over 80 . An interesting fact is that women are found in greater numbers in cities and towns. In cities and towns, the differences between the male and female population are already visible in the age group between 25 and 29. In total, the population that lives in towns and cities is relatively younger than those people that live in other areas. ${ }^{30}$

The intensified process of the aging of the population in Serbia is conditioned, among other things, by an increase in the number of elderly households. At the same time, the gender balance within the older population is disrupted, the circumstance that women live longer than men and are more in numbers among the elderly in Serbia, has as one of its consequences the increase in households in which older women live alone.

The very fact that women constitute the majority in the elderly population further underscores the importance of exploring the gender aspects of aging and the analysis of various implications of the feminization of old age.

\section{Presentations and Perceptions of Old Age}

The social image and representations of old age, the ways in which it is shaped, change depending on the historical, social, and cultural context. Different presentations of old age are conditioned by different socio-cultural influences, socially accepted and dominant values, but those presentations also have changed through time.

29 Жене и мушкарци у Републищи Србији 2017, 28.

30 Анкица Кубуровић, „Социо-демографске особености женског и мушког становништва централне Србије почетком прве деценије 21. века“, Становништво $1 / 2007,119,122$. 
The perception of old age in the twentieth century and in the first decades of the new millennium invokes different images, often incompatible and opposite. The difference between these images is even more emphasized and visible in the media presentation of old age. The media significantly affect the creation of the social image of the elderly. One of the dimensions and research questions related to the gender aspect of aging is also the presentation of old age, and especially women in "the third age" in the media. In that context, the image of old age in advertising is especially interesting.

The negative connotation in the way the media presented old people linked to commercials and advertising from the 1950s in the West, in the US, has slowly vanished. Presenting the elderly in advertising campaigns has changed from the 1980 s, making the markedly negative stereotypes disappear. ${ }^{31}$

The presentation of older women in advertising campaigns, even those linked to the fashion industry, are changeable depending on time and place. Toward the end of the twentieth century, Isabella Rossellini, being in her forties, was already considered "old" for further advertising campaigns of well-known cosmetic brands whom she used to model for. At the same time, another American cosmetics company was preparing a twenty-year old girl to be a top model in order to model the products of this company as well as possible in her forties. The different relationship these corporations had with "older models" was directly linked to the estimations that would lead to making greater profit. ${ }^{32}$ What is especially interesting and what may be viewed as a change in this trend is that Isabella Rossellini truly did stop working for the fashion company at 43 years old, whose model she had been up to that point, but the new company director invited her to return to that company at age $63 .^{33}$

Almost unimaginable up until recently, ${ }^{34}$ women in their eighth decade of life, sometimes even older, successful in their career choices, have started to become top models for different brands, proudly show-

31 Ljubica Milosavljević, "Zašto su namćori otišli iz komšiluka? Predstavljanje starosti u domaćoj televizijskoj reklami, ponovljeno istraživanje", Etnoantropološki problemi $1 / 2013,140$.

32 Željka Mudrović,"Starost i starenje ljudskog roda. Žensko muški aspekti starenja”, Revija za sociologiju, Vol. 28, No. 3-4, 1997, 202, 203.

33 „Kada je imala 43 godine rekli su joj da je prestara. Isti ljudi javili su joj se 20 godina kasnije: Pogriješili smo", Jutarnji list, 26. 2. 2018.

34 In cultures in which youth and beauty are elevated high on the pedestal of social values, almost obsessed with them, older women were very rare in the fashion industry. 
ing their wrinkles and their elderly, yet still slim bodies, wrapped up in the newest fashion trends. Is that an advertising trick based on including these age groups in the fashion industry, i.e. spending, aimed and directed, and the older population it thus addresses in that way, or is it possibly something else? Dictated by market and profit logic, the fashion industry, especially in more economically developed and wealthier parts of the world, has been attempting to entertain the older population as well. Counting on its purchasing power, it includes all older citizens. Concerning public figures, such presentations of old age are becoming even more pronounced. In the time of consumerism and continuous market expansion in search of new consumer groups, women of "the third age" have been recognized as an especially important group. The fashion and cosmetics industries have adjusted their products to women belonging to the upper and middle classes, who have proven to be a category of the population prepared to put aside significant sums of money for what they believe slows down the aging process and keeps them "eternally youthful."

Famous Italian actress Sophia Loren, who, aside from her superb talent and unforgettable roles, has marked the second half of the twentieth century with her beauty, at the start of her ninth decade of life, surrounded by youth and roses in an advertising video for the newest perfume of a top Italian fashion company, was the winning combination for that brand. ${ }^{35}$

The dominant perception of old age in Serbia is far from that image, and the day to day life of old women and the reality of daily life are even further away from it. The presentations of old women have gone beyond aesthetic presentations and the visual experience of old age.

According to research conducted by Lj. Milosavljević, in advertising campaigns in these areas, but only as an exception, older public figures that have high social reputations have begun to appear, presented with positive connotations, "put together" in ways that make them look more like forty-year-olds than members of the older population in Serbia. ${ }^{36}$

The presentation of old age, viewed through domestic advertisements, i.e. advertising media space, has recently undergone some changes here as well, "with the willingness of the consumerist culture to respect

35 Fashion giant Dolce \& Gabbana, even with her age, still recognizes her as an icon of beauty and entrusts her with the role of advertising film model for its perfume Dolce Rosa Excelsa (2016). With the music by Ennio Morricone, there is only one message - you much own it.

36 Ljubica Milosavljević, Ogledi iz antropologije starosti, (Beograd: Srpski genealoški centar, 2012) 113. 
the oldest participants." ${ }^{37}$ In researching this phenomenon, it is emphasized that the change in context has also enabled a change in the way the old are presented, which has been happening very slowly. Although "obviously negative views on the old are disappearing" from domestic advertisements, which were some of the main characteristics of advertisements from the previous period, the author concludes that the dominant opinions in society still define the old as part of the "category of burden, poverty, and all kinds of otherness." 38

The media presentation of old age ${ }^{39}$ impacts on the shaping of the image of the elderly and in a certain sense upholds, creates, or abolishes the stereotype of the elderly. Negative stereotyping of older women in the 1990s was portrayed through the words "unproductive, dependent, weak, old-fashioned, ugly, senile, lonely, useless, wrinkled, slow, boring." The positive image refers to the "useful granny," "mature women with experience," the "good mum," etc. ${ }^{40}$ The established opinions regarding older women partly add to the stereotypes on aging in general; negative, which connote "illness, old age, ugliness, mental setbacks, memory loss, uselessness, isolation, poverty, and depression," or positive, implying "politeness, wisdom, dependability, wealth, political influence, liberty, vivacity, and contentment." ${ }^{41}$ Still, the stereotypes about women aging faster than men are almost universal. A study of the dominant attitudes toward the aging of the Belgrade population also points to the inveteracy of such opinions in these areas, "it shows on women," "women deteriorate faster," "they become decrepit more rapidly, at least on the outside."42 Once again it is shown that the perception, collective presentations, and experiences regarding aging, and thus the ways in which we age, are not the same for men and women.

\section{The Depiction of Older Women on Film}

The contents which are written into the film characters of third age women offer different images of old age. There have not been many

37 Milosavljević, "Zašto su namćori otišli iz komšiluka?”, 145.

38 Ibid.

39 Analyzing the Media advertising within Television Commercials around these Parts and Representing Old Age in Them, Lj. Milosavljević believes that "no advertising climate avoided the building of advertising messages on stereotypes". Milosavljević, Ogledi iz antropologije starosti, 110.

40 Mudrovčić, „Starost i starenje ljudskog roda”, 193-205.

41 Erdman B. Palmore (1990), from: Anita Zovko, Jelena Vukobratović, "Percepcija starenja i društveno-medijska slika o starima”, Andragoške studije, broj 1, 2017, 113. Slavica Komatina, "Dominantne predstave o starosti", Stanovništvo 1-4, 2003, 155. 
old lady characters in domestic films, and when they do appear, they are generally less significant; old age is often portrayed through supporting roles. In randomly chosen cultural films in Yugoslav and Serbian cinematography, ${ }^{43}$ older women characters are shown in different ways, creating and placing the images of old age in different contexts.

In the award-winning film by Srđan Karanović, Petrijin venac [Petria's Wreath] (1980), ${ }^{44}$ based on the novel by Dragoslav Mihailović, the character of an older peasant woman is depicted through the role of the "evil mother-in-law." Although a supporting role, it builds the image of the three-way relationship between mother-in-law, daughter-in-law, and son, under the system of patriarchy deeply woven into family lives, relationships, and traditional roles in a rural family in a small mining town in Serbia before the outbreak of World War II, during and after the war. The character of the mother-in-law is placed between the husband and the wife as some kind of ever-present evil spirit. "Whatever you do isn't good enough for her." Disappointed that she didn't bring a dowry into the home, the mother-in-law never loved Petria. She had a strong influence on her son Dobrivoje, caused altercations between them, encouraged her son to adopt an aggressive behavior and physically "punish" Petria. She humiliated her untaught, illiterate, submissive daughter-in-law, did not offer her support even when it was necessary, "when it's in order." The mother-in-law, whose name we do not even learn in the film, makes Petria'slife of pain and suffering even worse. The image of the older woman is made more complex here by the fact that she is at the same time the motherin-law, an implication of negative contents and established presentations based on relationships between mother- and daughter-in-law in rural life, on the submission of the daughter-in-law, and on the position of women in rustic settings in the backdrop of patriarchal patterns of life at the time.

In a film by the same director, several years later (1982) Nešto između [Something In-Between], ${ }^{45}$ the characters of older and middle-aged women are introduced (mother, aunt), as well as the old lady character (granny). The story about love, friendship, the organization of Yugoslav so-

43 Films were selected at random instead of only using those solely thematically dedicated to the elderly.

44 The film Petrijin venac [Petria's Wreath] is one of the rare Serbian films which has a woman at its core, it is entirely focused on a female character, the main, Petria.

45 The film Nešto između [Something In-between] by Srđan Karanović received numerous domestic and international recognitions and prices. 
ciety between the two political blocs, ${ }^{46}$ between the East and the West, in the context of urban Belgrade, begins and ends with the old lady's words in a card game. The old woman is presented as a lady in the film, her cared for, aged hands which are adorned with a striking ring and painted nails, at the very beginning of the film, the director positions them at the center of attention, as she opens her cards and speaks with a Russian accent. The character of the loveable, curious old lady, whose obligingness (she makes coffee, serves desserts, brings flowers...), her smiling face, and politeness in different, even conflicting situations, created in an apartment where three different generations of people live, additionally burdened by the presence of a foreigner with different views, enters the movie frame, representing old age with positive undertones. Being wise and having life experience, which is obtained through many years, is woven into the final, symbolic words of the film, which she states. Speaking about a card game, she talks about life itself: "Sometimes you're lucky, sometimes you're not, but nothing because, in the end, there are other games: blackjack, draw, poker, tablanet, durak, and preferans. But you should play, play, play. What else is there?"

The representation of old age in different film genres also brings characters of comical old ladies into the comedy genre. In the film Paja i Jare, Kamiondžije [Paja and Jare, Truckers], a comedy from the 1970s $(1973)^{47}$ directed by Milo Đukanović, the older woman's character was assigned humorous comebacks in an amusing context during a conversation with Jare, one of the main characters of the film. "The tone" of her voice ${ }^{48}$ especially contributes to the building of the comical character, whose primary function is to entertain the viewers. The old lady with her hat only appears briefly in the movie frame, away from the main storyline, but the sequences and comical scenes that this character is placed in belong to the some of the most memorable parts of the film.

46 In the words of Srđan Karanović "The film was called Something In-Between and it literally dealt with everything that was 'in-between.' An American woman stayed in Belgrade 'in-between' New York and Istanbul; the story happened in the time 'inbetween' peace and war; the genre was 'in-between' melodrama and a romantic comedy; the emotional relations in the film were 'in-between' friendship and love; the action takes place in Yugoslavia which was 'in-between' the capitalist and socialist block; I wanted the film to, if I compared to a drink, be like a lemonade which had been mixed with bitter, strong alcohol". Cited from: Ildiko Erdei, "Film kao artefakt: Nešto između Srđana Karanovića“, Etnoantropološki problemi, god. 12, sv. 4, 2017.

47 The film was based on the television series Kamiondžije [Truckers], which aired in the same year.

48 The high-pitched, old lady voice is in contrast with her energetic performance when she speaks to the truck driver. 
In the domestic public, a discussion was started on the figure of the old woman who appears in Slobodan Šijan's Ko to tamo peva [Who's Singin' Over There] (1980), arguably the best Serbian film of all time. ${ }^{49}$ In this dark comedy, whose dialogues generations of Serbian film lovers remember and even know by heart, the figure of the old lady, which appears in this film, is interesting from the point of this text. The old lady is an extra in the film, sitting at the end of the bus the entire time, dressed in black and not saying a single word. She is merely a part of the film's scenography. However, the film's screenwriter Dušan Kovačević highlights the symbol the old lady represents. "The old woman in black represents Serbia, which is utterly isolated. She is an analogy for old people who were left by their families in some village in the middle of nowhere. They vegetate like that, having accepted their fate, and are not in the least interested about what is going on in the country or abroad but have rather created their own paradox of remembrance, habits, and melancholy." 50

Old age is represented in a completely different context through the character of granny Vida in Predrag Antonijević's film Mala [The Little One] (1991). Granny Vida, who kills a police officer in order to exact revenge for the death of her grandson, is only one in a line of many tragic characters in the film's narrative about injustice, delusions, poverty, and the gloomy life of a mother and daughter. The complexity of the female characters whose lives are determined by unfortunate circumstances, but also the male characters of the film, is complemented by the figure of the granny who lives alone with her grandson. She is presented as a kind-hearted, warm, and caring old lady, who helps as much as she can through the series of unfortunate events, even if it is only by offering lunch. When they kill her grandson, she is left with nothing. "There is nobody left here. He went before his time... Wait, a gun was left behind the deceased Miša, I imagine it's yours. I should return it to you so the child doesn't owe you. I should return the bullets too." With those words, she shoots the police

49 In the selection for the best 100 films of Serbian cinematography organized by the Yugoslav Film Archive Museum, according to the opinion of film critics, theorists, and professors, the comedy Ko to tamo peva [Who's Singin' Over There], directed by Slobodan Šijan, based on the script by Duško Kovačević, was declared the best Serbian film. Ivan Aranđelović, "'Ko to tamo peva' ponovo izabran za najbolji srpski film", Политика, 28. 12.2016, datum pristupa 11.5. 2019, http://www.politika.rs/ sr/clanak/371033/Ko-to-tamo-peva-ponovo-izabran-za-najbolji-srpski-film

50 "Da li ste uopšte primetili? Evo ko je misteriozna baba iz filma 'Ko to tamo peva'", Blic, 28. 3. 2017, datum pristupa 24. 4. 2019, https://www.blic.rs/zabava/vesti/dali-ste-je-uopste-primetili-evo-ko-je-misteriozna-baba-iz-kultnog-filma-ko-to-tamo/ xpk1z9w 
officer who killed her grandson, looking to avenge him. At the very end of the film we learn that she died in prison, "her heart broken because of Miša." In this emotional drama, the tragic situation in which the granny takes justice into her own hands and avenges her grandson, who lost his life without having committed murder, makes her both a victim and a killer. Although a supporting role, the character of granny Vida is intonated in a way that leaves a strong impression on the viewers.

In domestic cinematography, the characters of older women are presented in different ways depending on the context, the time in which the films were created, and the topic that they focus on. The presentation of the characters of older women in several randomly chosen films is mainly given as an illustration of the way in which third-age women are represented in films. Perceiving the wider, entire image of the representation of old age in films and the shaping of public presentation of third-age women through films would go beyond the scope of this paper and bring into the analysis numerous other Serbian and Yugoslav films.

\section{Conclusion}

There is still little research on the gender aspects of old age and aging from a woman's perspective in Serbia. The historical review of aging and the gender structure of the population, i.e. of the relationship between the male and female population in total, shows different tendencies. Accelerated demographic aging, but also the domination of women among the older population, becoming increasingly pronounced in later years, and the feminization of old age, bring to the fore the consequences and effects of those phenomena on social everyday life and overall development. The public image and dominant presentation of old age are dependent on the social and historical context. The effect of the mass media on the shaping of the social image of the old, the presentation and perception of old age, is significant. At the same time, the media representations of older people and women of the "third age" often support different stereotypes, project them, or are based on them. The representation of older women in motion pictures is particularly interesting, in domestic cinematography. The film characters of third-age women offer different images of old age, generally through smaller or supporting roles. Older women were generally marginalized in film narratives, but are sometimes shown through complex characters. 


\section{Summary}

The accelerated processes of demographic aging place Serbia among the countries with the oldest population in Europe. The situation in which nearly one fifth of the population is older than 65 significantly determines the total social development in Serbia and has strong economic and social implications. In that context, researching old age from different perspectives, the consequences and outcomes of aging, is of increasing importance. Certain research questions related to the gender aspect of aging are highlighted in this work. Mass media significantly affect the shaping of the image that society has of the elderly. At the same time, media representations of third-age women often support different stereotypes, or even project them. The representation of older women on film is observed in the text through several randomly chosen Serbian and Yugoslav films. The contents that go into the movie characters of third-age women offer different images of age. The figures of older women were generally marginalized in film narratives, but are sometimes expressed through very complex characters.

\section{Sources and Literature}

- $\quad$ Arhiv Jugoslavije. 142, 468, Zadružni savez Jugoslavije.

- $\quad$ Arhiv Srbije: Fond CK SKS, Komisija za narodnu vlast, k. 234; đ-75, f. 92.

- Istorijski arhiv Beograda. Konferencija za društvenu aktivnost žena, k. 3.

- $\quad$ Prethodni rezultati popisa stanovništva i domaće stoke u Kraljevini Srbiji 31. decembra 1910, knjiga peta. Beograd: Izdanje uprave državne statistike, 1911.

- Statistički godišnjak Republike Srbije 2017. Beograd: Republički zavod za statistiku, 2017.

- $\quad$ Statistički godišnjak Republike Srbije 2018. Beograd: Republički zavod za statistiku, 2018.

- Žene i muškarci u Republici Srbiji. Beograd: Republički zavod za statistiku, 2017.

- Geiger Zeman, Marija. „, Kažu da prije stare žene nego muški' - starost i starenje kao relevantna feministička pitanja“. Treća, br. 1-2, vol. XVI, 2014, 5-11.

- Gudac Dodić, Vera. Žena u socijalizmu. Beograd, 2006. (cyrillic)

- Gudac Dodić, Vera. "Starenje ženskog stanovništva u Srbiji u drugoj polovini 20. veka". Gerontologija, časopis Gerontološkog društva Srbije, (Beograd), 2009, 143-153.

- Gudac Dodić, Vera. Life in Serbia, Through the Eyes of Women. Belgrade, 2014. 
- Devedžić, Mirjana, Jelena Stojilković Gnjatović. Popis stanovništva domaćinstava i stanova u 2011. Demografski profil starog stanovništva Srbije. Beograd: Republički zavod za statistiku, 2015.

- Dobrivojević, Ivana. Selo i grad, Transformacija agrarnog društva Srbije 1945-1955. Beograd: ISI, 2013.

- $\quad$ Erdei, Ildiko. "Film kao artefakt: Nešto između Srđana Karanovića". Etnoantropološki problemi, god. 12 sv. 4, 2017, 985-1011. DOI: 10.21301/eap. v12i4.2

- Zovko, Anita, Jelena Vukobratović. "Percepcija starenja i društveno-medijska slika o starima“. Andragoške studije, broj 1, jun 2017, 111-124. D0I: 10.5937/andstud1701111Z

- Isić, Momčilo. "Starosna struktura stanovništva u Srbiji početkom 20. veka posledice ratnih stradanja“. Gerontologija, časopis gerontološkog društva Srbije, (Beograd), 2009, 99-122.

- Jedvaj, Suzana, Ana Štambuk, Silvia Rusac. “Demografsko starenje stanovništva i skrb za starije osobe u Hrvatskoj". Socijalne teme: Časopis za pitanja socijalnog rada i srodnih znanosti, Vol. 1, No. 1, 2014, 135-154.

- Kuburović, Ankica. „Socio-demografske osobenosti ženskog i muškog stanovništva centralne Srbije početkom prve decenije 21. veka“. Stanovništvo 1/2007,119-126. (cyrillic)

- Komatina, Slavica. "Dominantne predstave o starosti". Stanovništvo 1-4, 2003, 147-160.

- Milosavljević, Ljubica. "Zašto su namćori otišli iz komšiluka? Predstavljanje starosti u domaćoj televizijskoj reklami, ponovljeno istraživanje". Етноантрополошки проблеми 1/2013, 117-148.

- $\quad$ Milosavljević, Ljubica. Ogledi iz antropologije starosti. Beograd: Srpski genealoški centar, 2012.

- $\quad$ Mudrović, Željka. “Starost i starenje ljudskog roda. Žensko muški aspekti starenja”. Revija za sociologiju, Vol. 28, No. 3-4, 1997, 193-205.

- $\quad$ Pavićević, Aleksandra. Na udaru ideologija. Brak, porodica i polni moral u Srbiji u drugoj polovini dvadesetog veka. Beograd: Etnografski institut SANU, 2006. (cyrillic)

- Penev, Goran. "Struktura stanovništva prema polu i starosti”. Popis stanovništva, domaćinstava i stanova 2011. u Republici Srbiji, Populacija Srbije početkom 21. veka, ur. Vladimir Nikitović. Beograd: Republički zavod za statisti$\mathrm{ku}, 2015,130-165$.

- Stojanović, Dubravka. “'U senci velikog narativa': Stanje zdravlja žena i dece u Srbiji početkom XX veka”, Žene i deca, Srbija u modernizacijskim procesima XIX i XX veka, 4, 162-163. Beograd, 2006.

- Šobot, Ankica. "Rodna neravnopravnost - izazov savremene demografije". Sociologija, vol. 52, br. 1, 2010, 41-54. DOI: 10.2298/SOC1001041S

- Šobot, Ankica. Rodna neravnopravnost u Srbiji: Demografsko gledište. Beograd: Institut društvenih nauka, 2014. 
- Šobot, Ankica. "Tri demografske posledice rodno specifičnih modela ponašanja na primeru Srbije”. Stanovništvo 2, 2012, 85-109.

- S Šobot, Ankica. "Demografski okvir rodne neravnopravnosti i kvalitetživota u starosti”. Geronotlogija, br. 1, 2011, 29-48.

- Jutarnji list

- $\quad$ http://data.stat.gov.rs/Home/Result/180708?languageCode=sr-Latn

- http://www.stat.gov.rs/sr-latn/publikacije/

- https://ourworldindata.org/gender-ratio\#definitions. Hannah Ritchie and Max Roser (2019) - “Gender Ratio". Published online at OurWorldInData.org

- http://www.politika.rs/sr/

- $\quad$ https://www.blic.rs

Films

- $\quad$ Ko to tamo peva. Slobodan Šijan. 1980.

- Mala. Predrag Antonijević. 1991.

- $\quad$ Nešto između. Srđan Karanović. 1982.

- $\quad$ Paja i Jare, Kamiondžije. Milo Đukanović. 1973.

- $\quad$ Petrijin venac. Srđan Karanović. 1980. 


\title{
Резиме
}

\author{
Вера Гудац Додић
}

\section{Старење у Србији у 20. веку: родна перспектива}

\begin{abstract}
Апстракт: У тексту су назначена нека истраживачка питања везана за родне аспекте старости. Дате су основне напомене о убрзаном демографском старењу, историјски осврт на процесе старења у Србији и указано је на полну неравнотежу међу старијим становништвом, односно на феминизацију старости. Представе и перцепције старости и старијих женских особа, као и њихово представљање на домаћем филму такође су део овог рада.

Кључне речи: демографско старење, феминизација старости, жене трећег животног доба, представљање старости
\end{abstract}

Убрзани процеси демографског старења у Србији смештају је међу државе са најстаријом популацијом у Европи. Стање у којем готово петина становника има више од 65 година значајно детерминише укупан развој друштва у Србији и има снажне економске и социјалне импликације. У том контексту, све је већи значај проучавања старости из различитих перспектива, последица и исхода старења. У овом раду назначена су поједина истраживачка питања везана за родне аспекте старења. Масовни медији значајно утичу на обликовање друштвене слике о старима. Истовремено, медијске представе жена трећег доба често подржавају различите стереотипе или их пак пројектују. Презентација старијих жена на филму у тексту се посматра у неколико насумично изабраних филмова српске и југословенске кинематографије. Садржаји у којима се срећу филмски ликови жена трећег доба нуде различите слике старости. Фигуре старијих жена углавном су биле на маргинама филмског наратива, али су некад исказане кроз веома комплексне ликове. 